\title{
Comparison of ecophysiological and leaf anatomical traits of native and invasive plant species
}

\author{
Ridesti Rindyastuti', Lia Hapsari ${ }^{1}$ and Chaeho Byun ${ }^{2^{*}}$ (B)
}

\begin{abstract}
Background: To address the lack of evidence supporting invasion by three invasive plant species (Imperata cylindrica, Lantana camara, and Chromolaena odorata) in tropical ecosystems, we compared the ecophysiological and leaf anatomical traits of these three invasive alien species with those of species native to Sempu Island, Indonesia. Data on four plant traits were obtained from the TRY Plant Trait Database, and leaf anatomical traits were measured using transverse leaf sections.

Results: Two ecophysiological traits including specific leaf area (SLA) and seed dry weight showed significant association with plant invasion in the Sempu Island Nature Reserve. Invasive species showed higher SLA and lower seed dry weight than non-invasive species. Moreover, invasive species showed superior leaf anatomical traits including sclerenchymatous tissue thickness, vascular bundle area, chlorophyll content, and bundle sheath area. Principal component analysis (PCA) showed that leaf anatomical traits strongly influenced with cumulative variances (100\% in grass and $88.92 \%$ in shrubs), where I. cylindrica and C. odorata outperformed non-invasive species in these traits.

Conclusions: These data suggest that the traits studied are important for plant invasiveness since ecophysiological traits influence of light capture, plant growth, and reproduction while leaf anatomical traits affect herbivory, photosynthetic assimilate transport, and photosynthetic activity.
\end{abstract}

Keywords: Plant traits, Invasive, Sempu Island, Imperata cylindrica, Lantana camara, Chromolaena odorata

\section{Background}

Invasive alien species (IAS) are considered a serious threat to an ecosystem because of their potential negative impact on the environment, agriculture, economy, and human health (CBD 2010; Roger 2003). Successful invasion by alien plant species is promoted by many factors that increase their competitiveness over that of co-occurring native plants. Alien plant invasion can change species composition, thus affecting biodiversity and hindering

\footnotetext{
* Correspondence: chaehobyun@anu.ac.kr; chaeho.byun@mail.mcgill.ca ${ }^{2}$ Department of Biological Sciences and Biotechnology, College of Life Sciences \& Biotechnology, Andong National University, 1375 Gyeongdong-ro, Andong, Gyeongsangbukdo 36729, Korea

Full list of author information is available at the end of the article
}

productivity of the recipient ecosystem (Bajwa et al. 2016; Daehler 2003; Farnsworth and Meyerson 2003).

Alien plant invasion threatens the natural ecosystems around the world (CBD 2010), including the tropical area of Indonesian Archipelago (Tjitrosoedirdjo et al. 2016). Human migration and expansion are the main factors responsible for plant introduction, which is sometimes coupled with biological invasion. Tjitrosoedirdjo (2005) reported that approximately 1936 alien plant species belonging to 187 families were introduced into Indonesia. Many of these plant species successfully invaded conservation areas, causing significant environmental changes in the Halimun-Salak National Park (HSNP) (Junaedi and Dodo 2014), Mt. Gede Pangrango National Park (GPNP) (Kudo et al. 2014), Alas Purwo

(c) The Author(s). 2021 Open Access This article is licensed under a Creative Commons Attribution 4.0 International License, which permits use, sharing, adaptation, distribution and reproduction in any medium or format, as long as you give appropriate credit to the original author(s) and the source, provide a link to the Creative Commons licence, and indicate if changes were made. The images or other third party material in this article are included in the article's Creative Commons licence, unless indicated otherwise in a credit line to the material. If material is not included in the article's Creative Commons licence and your intended use is not permitted by statutory regulation or exceeds the permitted use, you will need to obtain permission directly from the copyright holder. To view a copy of this licence, visit http://creativecommons.org/licenses/by/4.0/. 
National Park (Hakim et al. 2005), Ijen Crater Nature Tourism Park (Hapsari et al. 2014), Bawean Island montane forests (Trimanto and Hapsari 2016), and Baluran National Park (Sutomo et al. 2016).

Recent studies revealed that a small protected island in Indonesia, known as Sempu Island Nature Reserve, is currently encountering the spread of invasive alien plant species (Rindyastuti et al. 2018a; Hapsari et al. 2020). The Sempu Island, with an area of $877 \mathrm{ha}$, is located in the southern part of Java Island and is governed by the regional administration of Malang Regency, East Java Province, Indonesia. Sempu harbors diverse natural and tropical forest ecosystems that contain more than 360 plant species (Rindyastuti et al. 2018a) and common fauna of the Sunda Island (Sukistyanawati et al. 2016). However, the unique morphological and ecological characteristics of small islands, such as limited land area, small plains, limited fresh water, and isolated location, make the inhabiting species more vulnerable to both natural and anthropogenic factors such as climate variability, invasive alien species, natural catastrophes, and limited natural resources (Nurse et al. 2001; Calado et al. 2014).

Ecophysiological plant traits related to plant productivity such as relative growth rate (RGR) and specific leaf area (SLA) were consistent determinants in plant invasion. Invasive woody plants which showed high RGR were supported by having higher SLA than the natives (Grotkopp and Rejmánek 2007). Moreover, many recent studies revealed that reproductive dispersion traits such as seed dry mass, seed dispersal method, seed production, and plant height are highly correlated with biological invasion, both depending on and independent of other factors (Moodley et al. 2013; Moravcová et al. 2015). Herbaceous species taller than $0.8 \mathrm{~m}$ are likely to be invasive without other specification because it can disperse their seeds further, while shorter species develops dispersal method by animals; additionally, shorter species with small seed but less efficient animal dispersal can still be invasive by producing a large number of propagules (Moravcová et al. 2015). Anatomical advantages often enhance the physiological performance of plants through tolerance, adaptation, and competitive behavior (Perez-Harguindeguy et al. 2013; Hameed and Ashraf 2009). Studies on invasive species found in the Indonesian Archipelago are insufficient to explain biological invasion in the tropical regions of Asia. Therefore, in this study, we aimed to determine the ecophysiological and leaf anatomical traits of native and invasive plant species, including shrubs and grass, and their correlation with species invasiveness in the Sempu Island Nature Reserve, Indonesia. The results of this study would contribute to local and global knowledge of plant invasion, especially in tropical regions, which would help design conservation management practices.

\section{Results}

\section{Ecophysiological traits}

We compared the ecophysiological traits of 27 native and three invasive (Imperata cylindrica, Lantana camara, and Chromolaena odorata) plant species in Sempu Island, Indonesia. The SLA of L. camara and C. odorata were higher than those of all 10 native species in Sempu Island and Java mainland (Fig. 1a), indicating that invasive species outperformed all native life forms including shrubs and trees. Analysis of variance (ANOVA) revealed that the SLA of invasive and native species were significantly different $(P=0.006)$ (Fig. $1 \mathrm{~b}$; Table 2). In addition, the seed dry weight of all three invasive species was lower than that of all native species (Table 1) and ANOVA revealed that this difference was significant (Fig. 2b; Table 2).

Leaf photosynthetic rates per unit leaf dry weight of all three invasive species, including C. odorata, L. camara, and $I$. cylindrica, were higher than those of native species, especially Spondias pinnata (Fig. 3a); however, the average photosynthetic rates showed no significant difference between invasive and native species (Fig. 3b; Table 2). Additionally, the plant height of two invasive species, L. camara and I. cylindrica, was lower than that of nine native plant species (Fig. 4a); however, the average plant height of invasive and native plants showed no significant differences in both woody $(P=0.38)$ and non-woody $(P=0.33)$ categories (Fig. 4b; Table 2$)$.

\section{Leaf anatomical traits}

We performed a comparative analysis of the leaf anatomical traits of one invasive species (I. cylindrica) and two native species (Ischaemum muticum and Thuarea involuta). Qualitative anatomical traits that contributed to high competitiveness of invasive species included the succulence of leaves, shape of leaf midrib, development of bulliform cells, total arch number of vascular bundles, presence of sclerenchymatous tissue in vascular bundles and midrib, and development of bundle sheath and cell layers in leaf midrib and veins. The invasive species $I$. cylindrica showed three types of sclerenchymatous cells: sclerenchymatous cells in the upper leaf, sclerenchymatous cells in the midrib, and sclerenchymatous cells in the epidermal tissue ( $P$ values: $0.005,0.009,0.018,0.001$, and 0.016 , respectively) (Table 3 ).

Additionally, I. cylindrica showed a higher arch number of vascular bundles (Table 3) and a larger vascular bundle area than two other grass species (Table 4). The native species $T$. involuta showed the second highest plant performance and vascular bundle area after $I$. cylindrica. Additionally, invasive species exhibited superior anatomical traits, such as highly developed bundle sheath than native species. Among the natives, I. muticum showed lower leaf succulence and thicker leaf to 


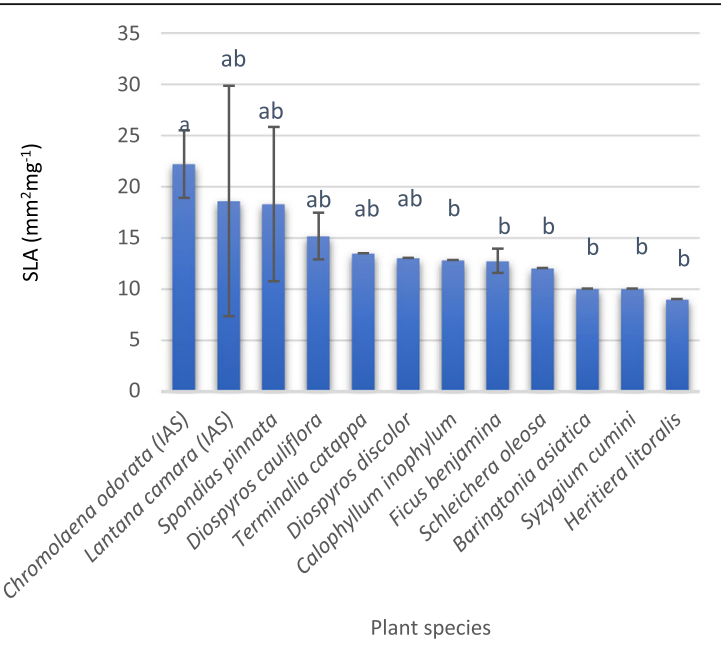

(a)

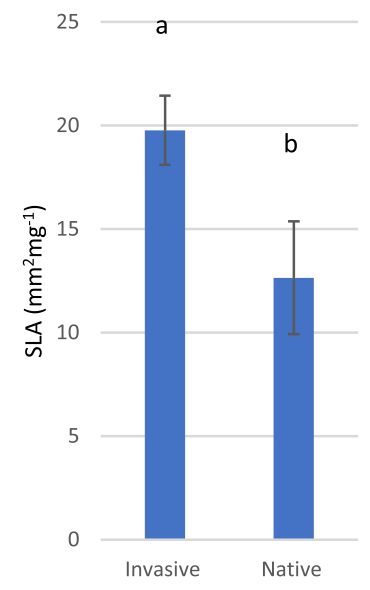

(b)

Fig. 1 Specific leaf area (SLA) of invasive and native plant species in Sempu Island, Indonesia. a SLA of each species. b Comparison of SLA between invasive and native species. Data represent mean \pm standard deviation (SD). Different lowercase letters indicate statistically significant differences (ANOVA and Tukey's test; $P \leq 0.05$ ). IAS, invasive alien species

prevent herbivory (Table 2). In comparison with I. muticum, $T$. involuta showed more competitive quantitative anatomical traits, especially larger bundle sheath area and higher chlorophyll content (Table 4). The invasive grass species $I$. cylindrica possessed thicker sclerenchymatous tissue than the two other grass species. Among the quantitative traits of grass, leaf thickness, bundle sheath area, vascular bundle area, sclerenchymatous tissue thickness, and chlorophyll content showed significant differences between invasive and native species (Table 3 ).

Two invasive shrub species (L. camara and C. odorata) and three native shrub species (Wollastonia biflora, Phempis acidula, and Casearia flavovirens) were also included in this analysis. Both invasive species possessed succulent leaves with dense, multi-serrated, and long trichomes. Based on the statistical analyses of quantitative traits, three leaf anatomical traits showed significant differences among species including vascular bundle area $(P=0.011)$, spongy mesophyll thickness $(P=0.031)$, and total chlorophyll content $(P=0.046)$. The invasive species $C$. odorata exhibited the largest vascular bundle area and the highest chlorophyll content compared with the invasive shrub and other native species (Table 5). These data suggest that $C$. odorata exhibits high ecological performance. On the other hand, the invasive shrub $L$. camara showed a smaller vascular bundle area than

Table 1 Seed dry weight of invasive and native species

\begin{tabular}{|c|c|c|}
\hline Species & Number of plant samples & Seed dry weight (mg) \\
\hline Lantana camara (IAS) & 4 & $5 \pm 4^{e}$ \\
\hline Chromolaena odorata (IAS) & 3 & $0.39 \pm 0.21^{\mathrm{e}}$ \\
\hline Imperata cylindrica (IAS) & 2 & $0.1 \pm 0.0042^{\mathrm{e}}$ \\
\hline Spondias pinnata & 1 & $10000^{a}$ \\
\hline Ceriops decandra & 1 & $2740^{b}$ \\
\hline Terminalia catappa & 3 & $2473 \pm 1401^{b}$ \\
\hline Croton tiglium & 1 & $218^{c}$ \\
\hline Vitex trifolia & 1 & $99^{c}$ \\
\hline Sophora tomentosa & 1 & $71^{\mathrm{c}}$ \\
\hline Ipoemea pes caprae & 1 & $45^{\mathrm{cd}}$ \\
\hline Ficus benjamina & 1 & $25 d$ \\
\hline Morinda citrifolia & 1 & $15^{\overline{\mathrm{de}}}$ \\
\hline
\end{tabular}

Data represent mean \pm standard deviation (SD). Different lowercase letters indicate statistically significant differences (ANOVA and Tukey's test; $P \leq 0.05$ ). IAS, invasive alien species 


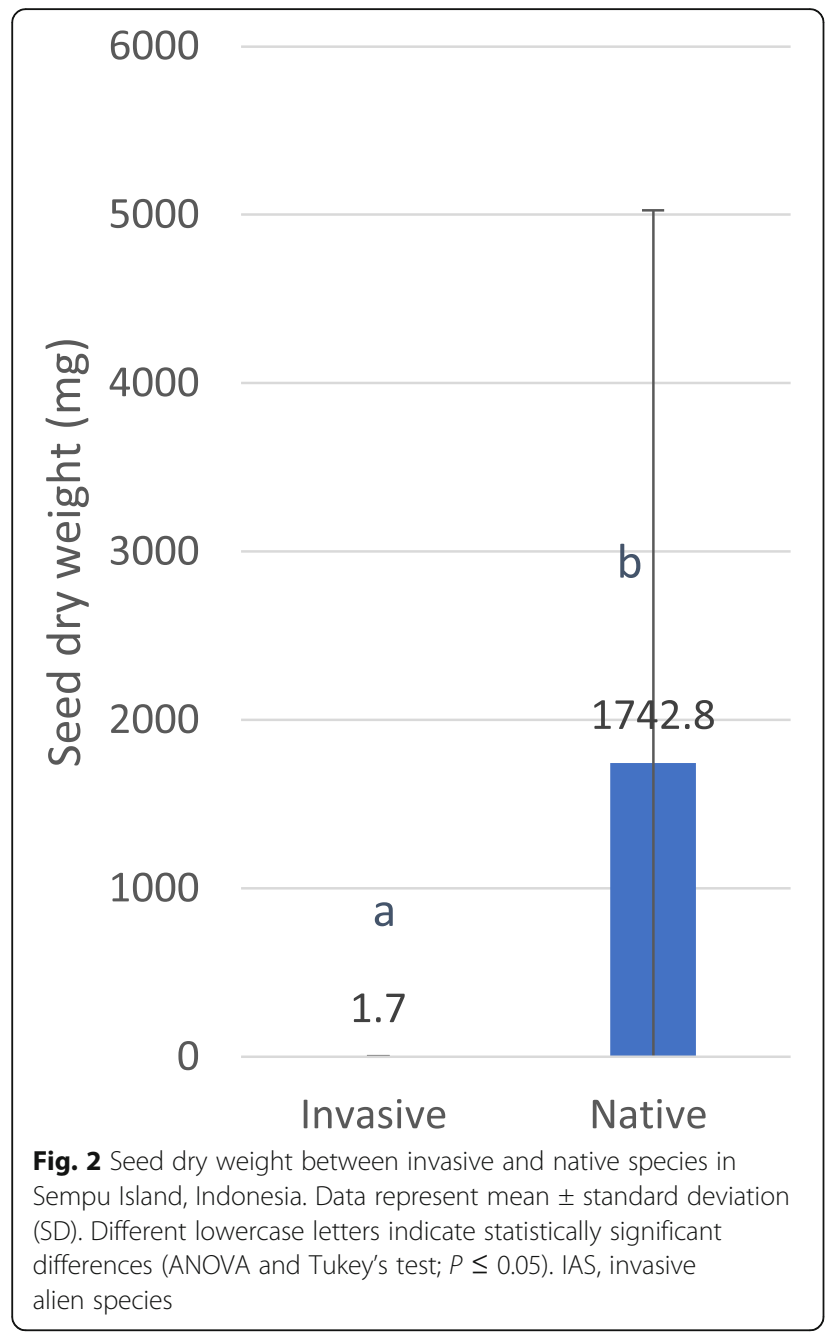

most native species, especially $C$. flavovirens and $W$. biflora. Additionally, the chlorophyll content of $L$. camara was low, indicating low carbon capture capacity.

\section{PCA of leaf anatomical traits}

Ecophysiological and leaf anatomical traits observed in this study were predicted as determinants of plant performance and invasiveness. PCA was carried out separately for shrubs and grass because both life forms exhibit distinct leaf anatomical characteristics. PCA of quantitative leaf anatomical traits of grass revealed only two principal components, with Eigenvalues of 7.02 and 4.98, which together accounted for $100 \%$ of the total variance. The native species $T$. involuta showed a strong positive association with leaf anatomical traits including total chlorophyll content, mesophyll thickness, bundle sheath area, and bulliform cell thickness, similar to the invasive grass species $I$. cylindrica. In addition to these traits, I. cylindrica also showed a positive association with other important traits such as sclerenchymatous tissue thickness, bulliform cell area, and vascular bundle area (Fig. 5a).

On the other hand, the PCA of quantitative leaf anatomical traits of shrubs revealed five principal components. The first three principal components (PC1, PC2, and PC3) of the PCA showed Eigenvalues of 3.57, 3.17, and 2.14 , respectively, accounting for $88.92 \%$ of the total variance. PC1 and PC3 of shrubs showed that one invasive species, C. odorata, had superior leaf anatomical traits than the invasive shrub $L$. camara and native shrubs i.e. in vascular bundle area and chlorophyll content (Fig. 5b).

\section{Discussion}

\section{Ecophysiological traits of invasive plants}

Plant traits related to biological invasion vary among studies, depending on study sites and plant taxa (Drenovsky et al. 2012). Nonetheless, these studies reveal a common pattern, i.e., invasive plant species outperform native species (Rejmánek and Richardson 1996; van Kleunen et al. 2010). According to previous studies, ecophysiological traits associated with invasive behavior in plants include high leaf construction cost, SLA, and net $\mathrm{CO}_{2}$ assimilation (Baruch and Goldstein 1999); rapid and substantial allocation to root mass, heteroblasty, and strong $\mathrm{N}$ fixation ability (Morris et al. 2011); high RGR and SLA in woody angiosperms (Lambers and Poorter 1992; Grotkopp and Rejmánek 2007); high photosynthesis capacity and net photosynthesis (Pattinson et al. 1998; Mcdowell 2002).

In this study, invasive species showed superior ecophysiological traits which represented greater resource uptake, faster plant growth, and higher sexual reproduction than native species. SLA and leaf area per leaf dry mass relates to the capacity of carbon capture and photosynthetic activity by plant leaves, while plant height and seed dry

Table 2 Analysis of variance (ANOVA) of ecophysiological traits of native and invasive plant species in Sempu Island, Indonesia

\begin{tabular}{|c|c|c|c|c|}
\hline Ecophysiological traits & Degrees of freedom (DF) & Mean sum of squares (MS) & $F$ & $P$ value \\
\hline Specific leaf area (SLA) & 1 & 84.56 & 12.14 & 0.006 \\
\hline Seed dry weight & 1 & 15.16 & 15.75 & 0.003 \\
\hline Leaf photosynthetic rate per unit leaf dry weight & 1 & 0.012 & 1.35 & 0.330 \\
\hline Plant height (woody species) & 1 & 58.9 & 0.85 & 0.38 \\
\hline Plant height (non-woody species) & 1 & 0.39 & 3.08 & 0.33 \\
\hline
\end{tabular}




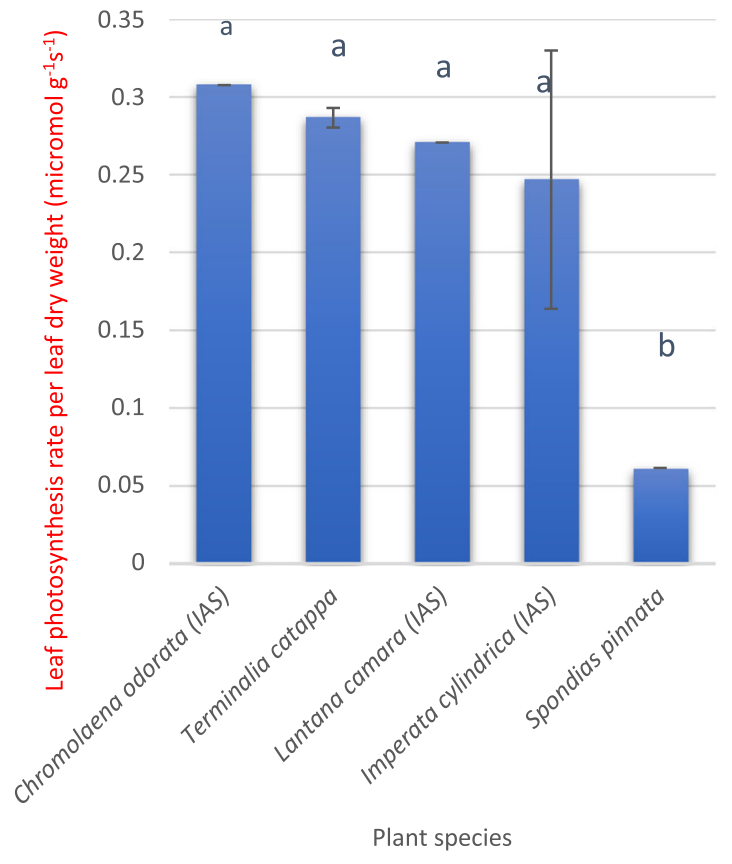

(a)

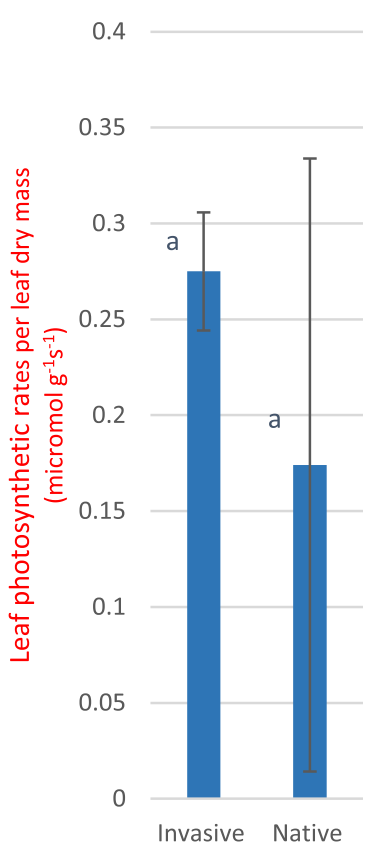

(b)

Fig. 3 Leaf photosynthetic rate per unit leaf dry weight of invasive and native plant species in Sempu Island, Indonesia. a Leaf photosynthetic rate per unit leaf dry weight of each species. $\mathbf{b}$ Comparison of leaf photosynthesis rates per unit leaf dry weight between invasive and native species. Data represent mean \pm standard deviation (SD). Different lowercase letters indicate statistically significant differences (ANOVA and Tukey's test; $P \leq 0.05)$. IAS, invasive alien species

weight relate to dispersal ability of seed for sexual reproduction. As the results, only two ecophysiological traits of invasive species (SLA and seed dry weight) significantly outperformed those of native species (Figs. 1 and 2) based on ANOVA (Table 2). SLA is a significant predictor of plant invasiveness and influences variation in RGR across herbaceous species (Poorter and Remkes 1990) and forbs (James and Drenovsky 2007). High SLA of invasive plants facilitates greater sunlight capture, more $\mathrm{CO}_{2}$ assimilation during photosynthesis, and rapid growth rate; all these factors are advantageous for biological invasion (Pugnaire and Valladares 1999; Shipley 2002; Lambers et al. 1998; Baruch and Goldstein 1999; Leishman et al. 2007; Gallagher et al. 2014). Invasive species exhibit higher SLA than native species (Burns and Winn 2006).

High SLA, along with high RGR, is associated with low seed weight, which is critical for a successful invasion in the genus of Pinus (Grotkopp et al. 2002). However, in Acacia and Acer, SLA is more closely associated with invasiveness than RGR (Grotkopp and Rejmánek 2007). The invasive species Rhus typhina exhibits different leaf functional traits, especially SLA, and resource-use strategy compared with native species (Wang et al. 2016). SLA is a plant trait that may be affected by environmental variables, such as gradient of nutrient and the level of habitat disturbances (Pattinson et al. 1998). These study results were interpreted from the combined data of TRY database and measurements on Indonesian plants. This may lead to a generalized conclusion based on the various data of SLA from different locations with a wide gradient of environmental conditions. In addition, the SLA of invasive species reported by Pattinson et al. (1998) was still the highest even was compared with the native species from nutrientrich sites, and lastly natives from undisturbed sites.

Invasive species also showed lower seed dry weight than the co-occurring native species (Fig. 2). Seed is an important generative ecological entity representing the allocation strategy and life cycle of plants. Seeds are produced by mature plants as naturally and genetically unique small organs, which serve as dispersal agents and enable species survival by remaining dormant until the environmental conditions are favorable (Fenner 1985). Smaller seed weight is associated with higher seed number (of similar weight), greater fertility, abundant seed bank (Banovetz and Scheiner 1994), high initial germination, and shorter chilling period needed to overcome dormancy (Westoby 1998; Rejmánek 1995). Small seeds reach distant geographical sites are long-lived (Hodkinson et al. 2002), experience lower predation, and therefore persist in the soil for a longer duration than larger seeds (Graebner et al. 


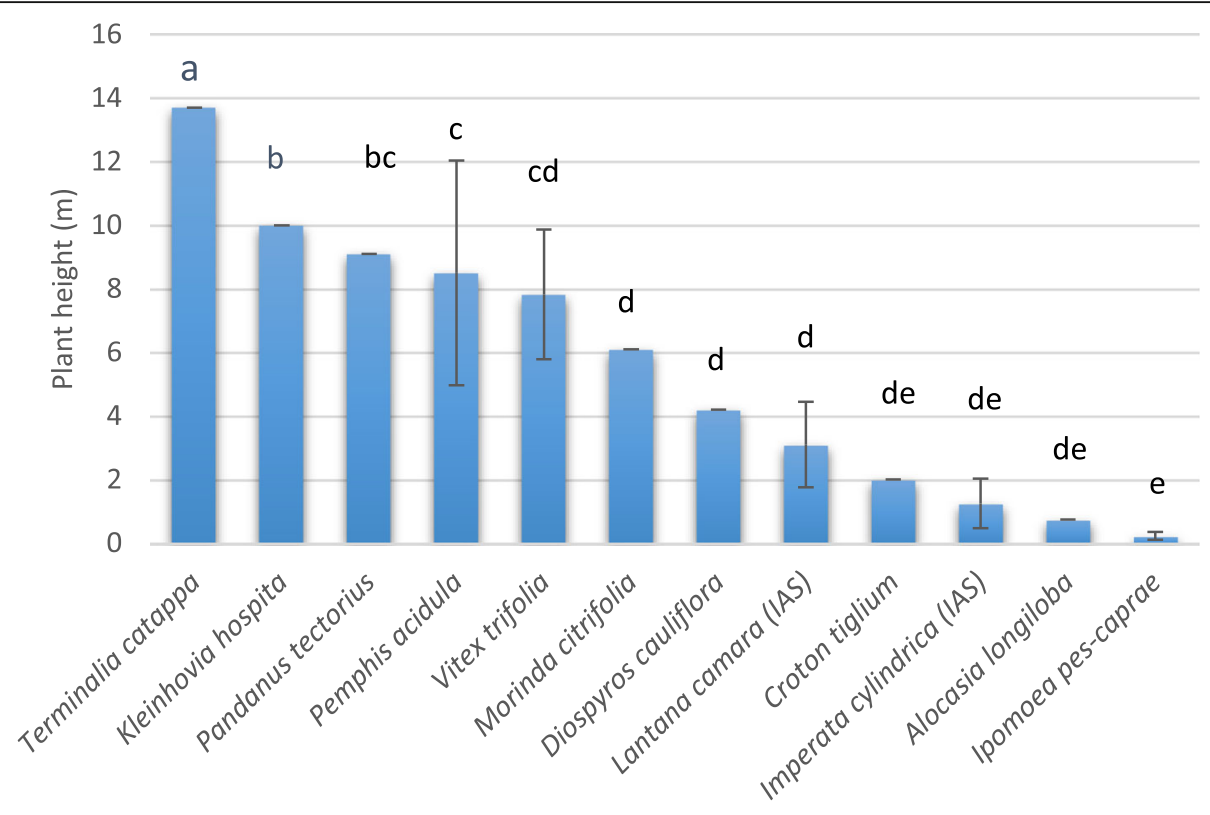

Plant species

(a)

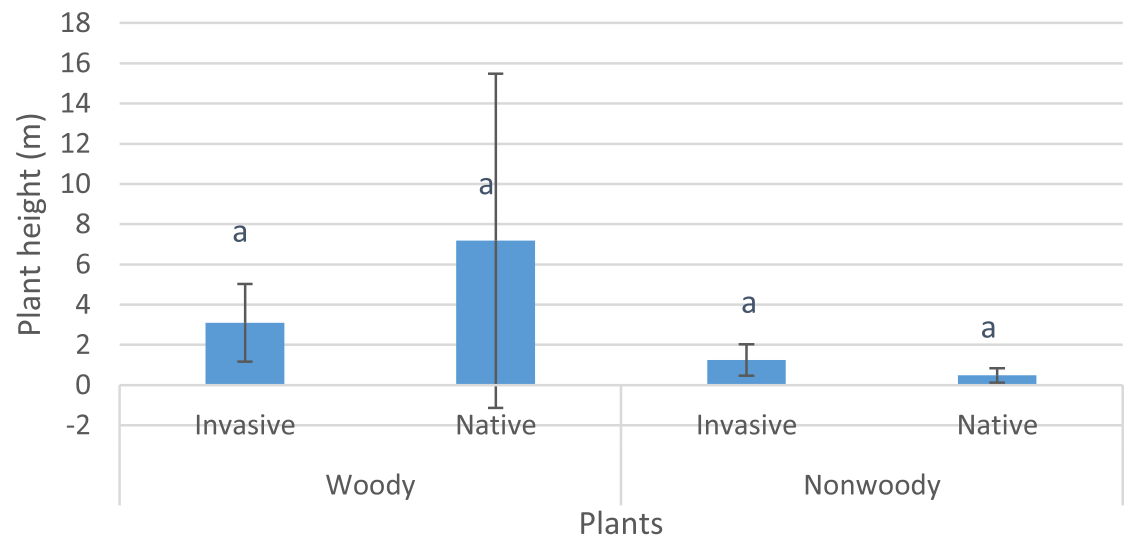

(b)

Fig. 4 Plant height of invasive and native plant species in Sempu Island, Indonesia. a Plant height of each species. b Comparison of plant height between invasive and native species in woody and non-woody categories. Data represent mean \pm standard deviation (SD). Different lowercase letters indicate statistically significant differences (ANOVA and Tukey's test; $P \leq 0.05$ ). IAS, invasive alien species

2012; Greene and Johnson 1993; Thompson et al. 1993; Westoby et al. 1992). Small seeds (dry weight $<2 \mathrm{mg}$ ) are predicted to influence plant invasiveness not only in the understory but also in woody invaders (Rejmánek 1996). Thus, small seeds have many benefits over large seeds that facilitate their invasiveness, resulting in large populations and rapid colonization, especially in disturbed habitats (Rejmánek and Richardson 1996), such as in Sempu Island, especially its coastal areas (Hapsari et al. 2020).

Dispersal traits are critical determinants in invasion success. Because invasion success is a multifaceted phenomenon, one trait could affect another trait. Seed dry weight was proved as one of the dispersal traits that significantly influence invasion success and this trait affects seed production (Moravcová et al. 2015). Seeds of the invasive species $C$. odorata are small (length: 3-5 $\mathrm{mm}$; width: $\sim 1 \mathrm{~mm}$; weight: $\sim 2.5 \mathrm{mg}$ per seed) (Vanderwoude et al. 2005). C. odorata is highly prolific, producing up to 260,000 seeds $/ \mathrm{m}^{2}$ (Witkowski and Wilson 2001), of which approximately $20-46 \%$ of seeds remain viable for up to 5 years. These small seeds are covered with numerous hairs, and are therefore easily blown and 
Table 3 Qualitative anatomical traits of shrubs and grass in Sempu Island, Indonesia

\begin{tabular}{|c|c|c|c|c|c|c|c|c|}
\hline \multirow[t]{2}{*}{ Anatomical traits } & \multicolumn{3}{|l|}{ Grass } & \multicolumn{5}{|l|}{ Shrubs } \\
\hline & $\begin{array}{l}\text { Thuarea } \\
\text { involuta }\end{array}$ & $\begin{array}{l}\text { Imperata } \\
\text { cylindrica }\end{array}$ & $\begin{array}{l}\text { Ischaemum } \\
\text { muticum }\end{array}$ & $\begin{array}{l}\text { Wollastonia } \\
\text { biflora }\end{array}$ & $\begin{array}{l}\text { Lantana } \\
\text { camara }\end{array}$ & $\begin{array}{l}\text { Chromolaena } \\
\text { odorata }\end{array}$ & $\begin{array}{l}\text { Phempis } \\
\text { acidula }\end{array}$ & $\begin{array}{l}\text { Caeseria } \\
\text { flavovirens }\end{array}$ \\
\hline Leaf midrib shape & Flat & $\begin{array}{l}\text { Conical, } \\
\text { prominent }\end{array}$ & Rounded & Rounded & Rounded & Rounded & Rounded & Rounded \\
\hline Trichome & $\begin{array}{l}\text { Long, } \\
\text { unicellular }\end{array}$ & $\begin{array}{l}\text { Short, } \\
\text { unicellular }\end{array}$ & $\begin{array}{l}\text { Short, } \\
\text { unicellular }\end{array}$ & $\begin{array}{l}\text { Long, } \\
\text { unicellular }\end{array}$ & $\begin{array}{l}\text { Dense, long, } \\
\text { multicellular }\end{array}$ & $\begin{array}{l}\text { Long, } \\
\text { multicellular }\end{array}$ & $\begin{array}{l}\text { Short, } \\
\text { unicellular }\end{array}$ & $\begin{array}{l}\text { Long, } \\
\text { unicellular }\end{array}$ \\
\hline Bulliform cells & Developed & $\begin{array}{l}\text { Highly } \\
\text { developed }\end{array}$ & $\begin{array}{l}\text { Highly } \\
\text { developed }\end{array}$ & Absent & Absent & Absent & Absent & Absent \\
\hline $\begin{array}{l}\text { Number of palisade } \\
\text { layers }\end{array}$ & Absent & Absent & Absent & $3-4$ & Two & $1-2$ & $4-5$ & $2-3$ \\
\hline $\begin{array}{l}\text { Number of spongy } \\
\text { mesophyll layers }\end{array}$ & Absent & Absent & Absent & $8-9$ & $4-5$ & $6-7$ & $5-7$ & $4-5$ \\
\hline $\begin{array}{l}\text { Total arch number of } \\
\text { vascular bundle }\end{array}$ & $36-40$ & $42-45$ & $27-44$ & Unobserved & Unobserved & Unobserved & Unobserved & Unobserved \\
\hline $\begin{array}{l}\text { Sclerenchyma of } \\
\text { vascular bundle }\end{array}$ & Single layer & Many layers & 3-4 layers & Few layers & Absent & Absent & Absent & 2-3 layers \\
\hline Sclerenchyma of midrib & Absent & $\begin{array}{l}12-15 \\
\text { layers }\end{array}$ & 3 layers & Few layers & Absent & Absent & Absent & 2-3 layers \\
\hline $\begin{array}{l}\text { Sclerenchymatous cells } \\
\text { in upper leaf }\end{array}$ & Absent & 3 layers & Single layer & Absent & Absent & Absent & Absent & Absent \\
\hline $\begin{array}{l}\text { Sclerenchymatous } \\
\text { epidermal layers }\end{array}$ & Discontinuous & Continuous & Discontinuous & Absent & Absent & Absent & Absent & Absent \\
\hline Bundle sheath of midrib & $\begin{array}{l}\text { Highly } \\
\text { developed }\end{array}$ & $\begin{array}{l}\text { Highly } \\
\text { developed }\end{array}$ & Developed & Absent & Absent & Absent & Absent & Absent \\
\hline Bundle sheath of veins & $\begin{array}{l}\text { Well } \\
\text { developed }\end{array}$ & $\begin{array}{l}\text { Well } \\
\text { developed }\end{array}$ & Developed & Absent & Absent & Absent & Absent & Absent \\
\hline $\begin{array}{l}\text { Number of bundle } \\
\text { sheath cells in midrib }\end{array}$ & 13-14 cells & 19-22 cells & 13-15 cells & Absent & Absent & Absent & Absent & Absent \\
\hline $\begin{array}{l}\text { Number of bundle } \\
\text { sheath cells in veins }\end{array}$ & 4-9 cells & $4-13$ cells & 4-9 cells & Absent & Absent & Absent & Absent & Absent \\
\hline
\end{tabular}

dispersed by wind. Seeds are also spread by machinery, water, vehicles, animals, clothing, and contaminated forestry and agricultural tools (GISD 2015). Seeds of the invasive species $L$. camara are dispersed by fruit-eating birds and a few mammals (Priyanka and Joshi 2013). The invasive grass $I$. cylindrica is also highly prolific, producing over 3000 small seeds per plant (MacDonald
2004). Given the high seed production and dispersal, invasive species produce a large number of offspring, which facilitate species propagation and rapid spread in new environments. Moreover, prolific seed production of invasive species has significant implications on their invasive behavior, in connection with seed dispersal by wind (Marchante et al. 2010).

Table 4 Quantitative leaf anatomical traits of grass species

\begin{tabular}{|c|c|c|c|c|c|c|}
\hline \multirow[t]{3}{*}{ Species $^{z}$} & \multicolumn{6}{|c|}{ Leaf anatomical traits ${ }^{y}$} \\
\hline & $\begin{array}{l}\text { Leaf } \\
\text { thickness } \\
(\mu \mathrm{m})\end{array}$ & $\begin{array}{l}\text { Bulliform cell } \\
\text { area }\left(\mu \mathrm{m}^{2}\right)\end{array}$ & $\begin{array}{l}\text { Bundle sheath } \\
\text { area }\left(\mu \mathrm{m}^{2}\right)^{x}\end{array}$ & $\begin{array}{l}\text { Vascular bundle } \\
\text { area }\left(\mu \mathrm{m}^{2}\right)\end{array}$ & $\begin{array}{l}\text { Sclerenchymatous tissue } \\
\text { thickness }(\mu \mathrm{m})\end{array}$ & $\begin{array}{l}\text { Chlorophyll } \\
\text { content }(\mu \mathrm{m})\end{array}$ \\
\hline & $P=0.005$ & $P=0.145$ & $P=0.009$ & $P=0.018$ & $P=0.001$ & $P=0.016$ \\
\hline $\begin{array}{l}\text { Ischaemum } \\
\text { muticum (N) }\end{array}$ & $\begin{array}{l}139.35 \pm \\
18.81 b\end{array}$ & $7469 \pm 584.2 \mathrm{a}$ & $2585 \pm 540 c$ & $929.5 \pm 291 c$ & $25.3 \pm 5.205 a b$ & $14.13 \pm 1.27 b$ \\
\hline $\begin{array}{l}\text { Imperata } \\
\text { cylindrica (IAS) }\end{array}$ & $\begin{array}{l}163.66 \pm \\
16.225 b\end{array}$ & $\begin{array}{l}13,117.5 \pm \\
4017.9 \mathrm{a}\end{array}$ & $7710 \pm 3727 b$ & $8068 \pm 2432.5 a$ & $44.335 \pm 5.35 a$ & $12.6 \pm 1.5 b$ \\
\hline $\begin{array}{l}\text { Thuarea involuta } \\
\text { (N) }\end{array}$ & $\begin{array}{l}234.63 \pm \\
15.85 a\end{array}$ & $9691 \pm 3234.35 a$ & $16,454.5 \pm 5024.5 a$ & $5379.5 \pm 2810.6 b$ & $18.935 \pm 1.9 b$ & $26.1 \pm 7.2 \mathrm{a}$ \\
\hline
\end{tabular}

${ }^{\mathrm{z}} N$ Native species, IAS Invasive alien species

${ }^{y}$ Data represent mean \pm standard deviation (SD; $\left.n=15\right)$. Lowercase letters in each row indicate significant differences (ANOVA and Tukey's test; $\left.P<0.05\right)$

${ }^{\mathrm{x}}$ Quantitative leaf anatomical traits 
Table 5 Quantitative leaf anatomical traits of shrubs species

\begin{tabular}{|c|c|c|c|c|}
\hline \multirow[t]{3}{*}{ Species $^{z}$} & \multicolumn{4}{|l|}{ Anatomical traits ${ }^{y}$} \\
\hline & $\begin{array}{l}\text { Vascular bundle area } \\
\left(\mu \mathrm{m}^{2}\right)\end{array}$ & $\begin{array}{l}\text { Palisade thickness } \\
(\mu \mathrm{m})\end{array}$ & $\begin{array}{l}\text { Spongy mesophyll thickness } \\
(\mu \mathrm{m})\end{array}$ & $\begin{array}{l}\text { Total chlorophyll content } \\
(\mathrm{mg} / \mathrm{g})\end{array}$ \\
\hline & $P=0.011$ & $P=0.22$ & $P=0.031$ & $P=0.046$ \\
\hline Lantana camara (IAS) & $9594 \pm 3595 b$ & $56.66 \pm 7.4 a$ & $57.61 \pm 16 b$ & $12.93 \pm 4.6 b$ \\
\hline $\begin{array}{l}\text { Chromolaena odorata } \\
\text { (IAS) }\end{array}$ & $44,056.72 \pm 20,210 a$ & $63.91 \pm 20.5 a$ & $92.50 \pm 16.4 a b$ & $20.8 \pm 4.15 a$ \\
\hline Phempis acidula (N) & $8570 \pm 8185 b$ & $98.77 \pm 49.8 a$ & $77.02 \pm 9.4 a b$ & $22.6 \pm 9.54 a$ \\
\hline Caeseria flavovirens (N) & $38,163 \pm 12,232 a$ & $87.21 \pm 12.2 a$ & $115.54 \pm 23.2 a$ & $18.2 \pm 5.6 a b$ \\
\hline Wollastonia biflora $(\mathrm{N})$ & $19,725 \pm 8593 a b$ & $89.54 \pm 23 a$ & $98.6 \pm 18.7 a b$ & $7.67 \pm 0.15 c$ \\
\hline
\end{tabular}

${ }^{\mathrm{z}} \mathrm{N}$ Native species, IAS Invasive alien species

${ }^{y}$ Data represent mean \pm standard deviation (SD; $\left.n=15\right)$. Lowercase letters in each row indicate significant differences (ANOVA and Tukey's test; $P<0.05$ )

Two additional traits affecting ecological performance, namely leaf photosynthetic rate per unit leaf dry weight (micromol $\mathrm{g}^{-1} \mathrm{~s}^{-1}$ ) and plant canopy $(\mathrm{m})$ were superior in invasive plant species than in native species (Figs. 3 and 4). This study results reported that photosynthetic traits showed no significant differences between invasive and native species (Table 2). Leaf photosynthetic rate is correlated with primary productivity. Invasive species usually exhibit superior life performance and growth rates than native species (Mcdowell 2002; Pattinson et al. 1998). Non-significant photosynthetic rate maybe showed a life history strategy of invasive species to develop greater leaf area than to raise photosynthetic activity. Because with large leaf area, invasive shrubs species also take benefits to create shading for the seedling of native plants which prevent the natives dominated the habitat (Brym et al. 2011). This chosen strategy is more effective for plant growth and the success of plant invasion in new areas.

Plant height is related to plant ecological strategy, such as the ability to compete for light (Grime 1988; Moles et al. 2009; Gallagher et al. 2014). Invasive species are usually taller than their congeneric relatives (Westoby 1998; Gallagher et al. 2014). In addition, seeds of tall invasive species disperse farther than those of short invasive species (Thomson et al. 2011). Many species and plant samples were extracted for this trait and some of them are maximum height for the species studied. Hopefully, it could minimize the environmental variables that may affect the results and conclusions. However, no difference in the plant height was detected between invasive and native plant species. A previous study reported that plant height did not always correlate with invasion success (Hamilton et al. 2005). In addition, invasive species studied are included in shrub and grass which growing the population in the understory. Each life forms of plants demonstrated different life-history strategies. Invasive shrub often showed the characteristics of lightdemanding plants which has ecological strategic to display larger leaf area rather than develop a tall habit like invasive shrubs Elaeagnus umbellate (Brantley and Young 2009; Brym et al. 2011). When the invasive shrubs developed greater leaf area, it has disadvantages to grow shorter habit than the natives. Therefore, to invade an area, invasive shrubs would need to form large bushes which prevent the habitats from being overshaded by the natives (Brym et al. 2011).

Other ecological traits may affect the invasion success, such as the use of rhizome in plant reproduction. Cogon grass (I. cylindrica) performs vegetative reproduction besides sexual reproduction, it produces culms from creeping underground rhizomes that might increase its ability to spread faster at the invaded area. While C. odorata in invaded areas of China was reported to have higher biomass at opened habitat and perform shift biomass reallocation (from belowground into aboveground) (Liao et al. 2019). These traits were indicated as keys to its invasion success.

\section{Leaf anatomical traits of invasive species}

The combination of anatomical traits might be a key factor behind the success of invasive plants because it might contribute to plant growth in which an invasive exhibits superior ecological performance that contributes to its invasiveness. Riveron-Giro et al. (2017) reported superior anatomical characteristics on invasive orchids Oeceoclades maculata. It develops an air-filled chamber and wider mesophyll that reduce transpiration rate, velamen as a characteristic of xerophytic that increases access to minerals and nutrients and serves as mechanical support. The superiority of invasive $C$. odorata over its congeneric native species has been investigated by Foloruso and Awosode (2013). C odorata possess abundant sclerenchyma tissues which are an important component of the skeletal system, long but coiled trichomes for effective light piping, larger stomata but a low stomatal index to reduce evaporation to reserve water and protect plants from severe interference of photosynthetic function.

In this study, a deep analysis was performed to compare the leaf anatomical characteristics between invasive 


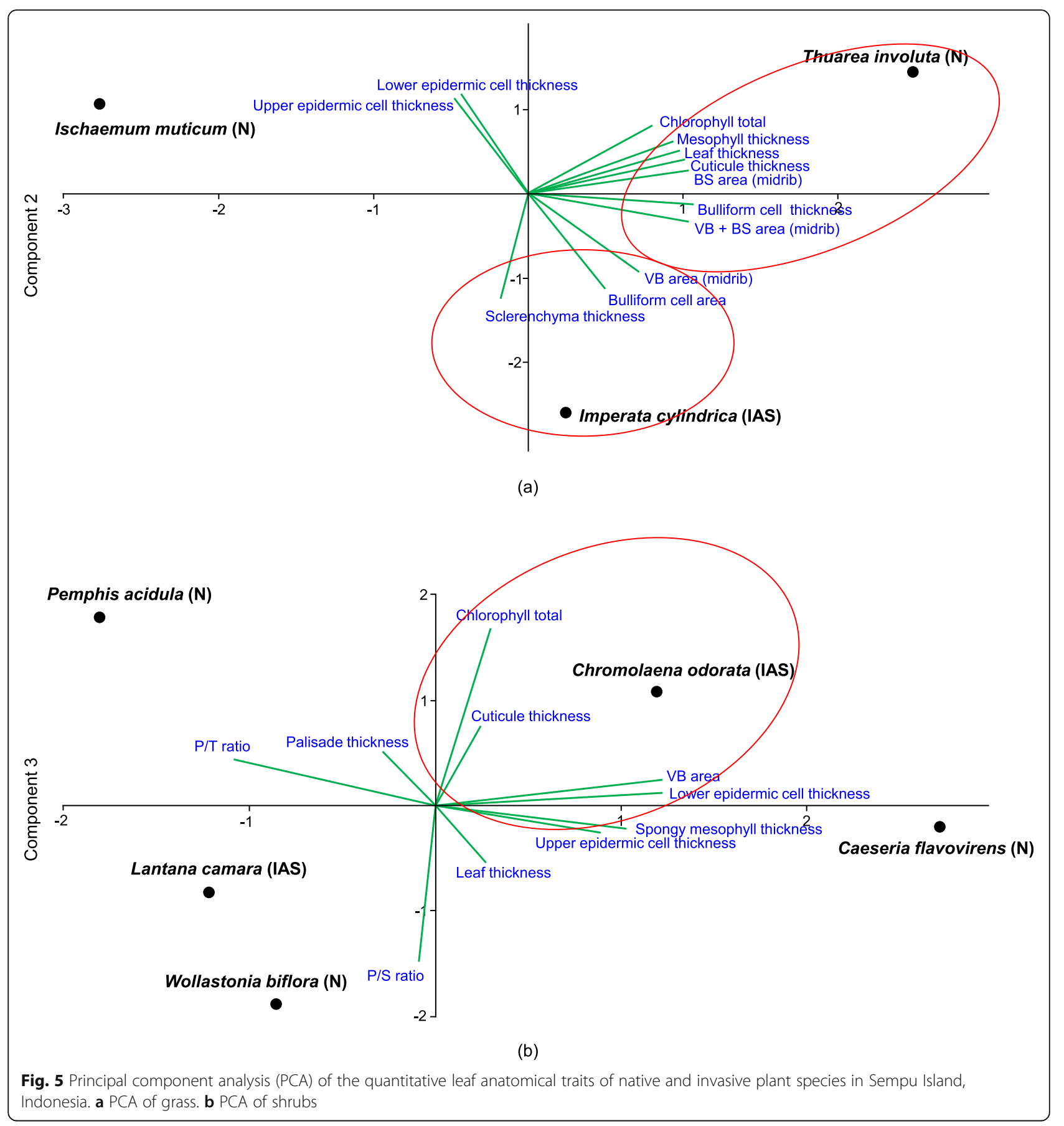

and native species in Sempu Island. Plant species were equally compared between invasive $\mathrm{C} 3$ with native $\mathrm{C} 3$ shrubs and between $\mathrm{C} 4$ grass with native $\mathrm{C} 4$ grass to consider differences in plant's life forms and physiological properties. As the results, invasive shrubs showed superior leaf anatomical traits, including sclerenchymatous tissue thickness, vascular bundle area, bundle sheath area, and total chlorophyll content than native species (Tables 3, 4, and 5). Sclerenchyma thickness correlates with food preferences for herbivores. Herbivory plays an important role in plant distribution (Maschinski 2001). According to Namagada et al. (2009), the sclerenchymatous layer is composed of thick-walled and lignified cells, which provide mechanical support to the plant and influences leaf softness, strength, and sharpness. The presence of sclerenchymatous tissue reduces the degree of leaf softness, which in turn reduces its likelihood of being consumed by herbivores. 
Both invasive shrub species, $C$. odorata and $L$. camara, showed multi-serrated leaves with dense and long trichomes, which deter feeding by herbivores (Priyanka and Joshi 2013). In addition, both $C$. odorata and $L$. camara are reportedly harmful to livestock, especially buffalos and cows; thus, both these species could rapidly colonize a natural habitat. By contrast, co-occurring native shrubs Wollastonia biflora exhibit smoother trichomes and are safe for use as fodder (Table 2); therefore, this species will be preferred by herbivores, which could repress their growth and abundance in nature.

The invasive C4 grass I. cylindrica exhibited medium leaf thickness, which was higher than the leaf thickness of native species but lower than that of the native grass T. involuta (Table 3 and 4). Furthermore, leaves of $I$. cylindrica possess serrated margins and accumulate silicates, resulting in a sharp and hard leaf texture, which deters herbivores (Dozier et al. 1998). Moreover, leaves of invasive grass species exhibit a conical, prominent, and thick sclerenchymatous midrib, while those of native species exhibit a flat and thin midrib (Dozier et al. 1998).

Vascular bundles, including xylem and phloem tissues, are important for transporting water, minerals, and photosynthetic assimilates (Fahn 1982). Vascular bundle area is an important trait that determines plant performance and environmental adaptation (Hameed and Ashraf 2009). The invasive grass species $I$. cylindrica showed a larger vascular bundle area than native species (Table 4), indicating higher ecological performance and greater water and assimilate transport. Among the invasive species, C. odorata showed a larger vascular bundle area than L. camara (Table 5).

Bundle sheath is an inner structure of $\mathrm{C} 4$ plant species, which is correlated with photosynthetic activity. C4 plants exhibit Kranz anatomy, which is characterized by enlarged collenchyma cells surrounding vascular bundles that contain photosynthetic enzymes and high chlorophyll content (Fahn 1982; Lack and Evans 2001). The Kranz anatomy supports the $\mathrm{C} 4$ pathway; the larger the bundle sheath, then the higher the $\mathrm{C} 4$ photosynthetic enzyme activities. The invasive grass I. cylindrica showed a significantly greater bundle sheath area than native species (Table 4). Large bundle sheath area allows invasive species to produce more assimilates during photosynthesis.

Chlorophyll is an important compound in the photosynthetic process which varies among plant species especially between the sun and shade-adapted plants (Sarijeva et al. 2007). Many research reported direct relationships between the quantity of chlorophyll and photosynthetic rates (Nagaraj et al. 2002;). In tropical woody species, the total chlorophyll content showed a strong association with total plant biomass (Rindyastuti et al. 2018b). In the correlation with plant invasion, photosynthetic traits related to carbon gain could directly influence plant growth and productivity which facilitate plants to invasion success by outperforming native or slower growing species (Mcalpine et al. 2008; McDowell 2002). Quan et al. (2015) reported that in the invasion of C. odorata in China, chlorophyll content did not limit photosynthetic rates. Contrary, C. odorata in Sempu Island showed high chlorophyll content together with the highest SLA and photosynthetic rate compared with many native species. This indicated the correlation between chlorophyll content and the ecological performance of invasive species in a given region.

\section{Conclusion}

Specific leaf area (SLA) and seed dry mass are two ecophysiological traits which showed significant influence on biological invasion in Sempu Island Nature Reserve, Indonesia. Besides taking advantages of ecological performances, invasive species in Sempu Island also performs better in leaf anatomical traits, i.e., in sclerenchymatous tissue thickness, vascular bundle area, chlorophyll content, and bundle sheath area than native species. PCA biplot showed that leaf anatomical traits strongly influenced the plant invasion in the principal components with cumulative variances $(100 \%$ in grass and $88.92 \%$ in shrubs), which showed I. cylindrica and C. odorata outperformed native species in these traits. The invasive grass I. cylindrica showed higher bulliform cell area, sclerenchymatous cell thickness, and vascular bundle area than native species, whereas the other leaf anatomical traits of I. cylindrica were similar to those of native species. The invasive shrub $C$. odorata is predicted to threaten the natural ecosystem more seriously than other invasive species by showing highly competitive ecological performances. Thus, to conserve native species, strategies are needed to mitigate the impact of this IAS.

\section{Materials and methods}

\section{Study area}

This study was conducted in the Sempu Island Nature Reserve located in Sempu Island (112 $400^{\prime} 45^{\prime \prime}$ to $112^{\circ} 42^{\prime} 45^{\prime \prime} \mathrm{E}$ and $8^{\circ} 27^{\prime} 24^{\prime \prime}$ to $8^{\circ} 24^{\prime} 54^{\prime \prime}$ ), a very small island (approximately $877 \mathrm{ha}$ ) situated approximately 800 $\mathrm{m}$ off the south coast of Java Island, Indonesia, at 0-102 $\mathrm{m}$ above the sea level. The eastern, southern, and western parts of the Sempu Island Nature Reserve are bordered by the Indian Ocean (Fig. 6). The island is a nature reserve managed by the Ministry of Forestry of Indonesia. Sempu Island has a dominant karst landscape, a relatively thin soil layer, and four tropical forest 


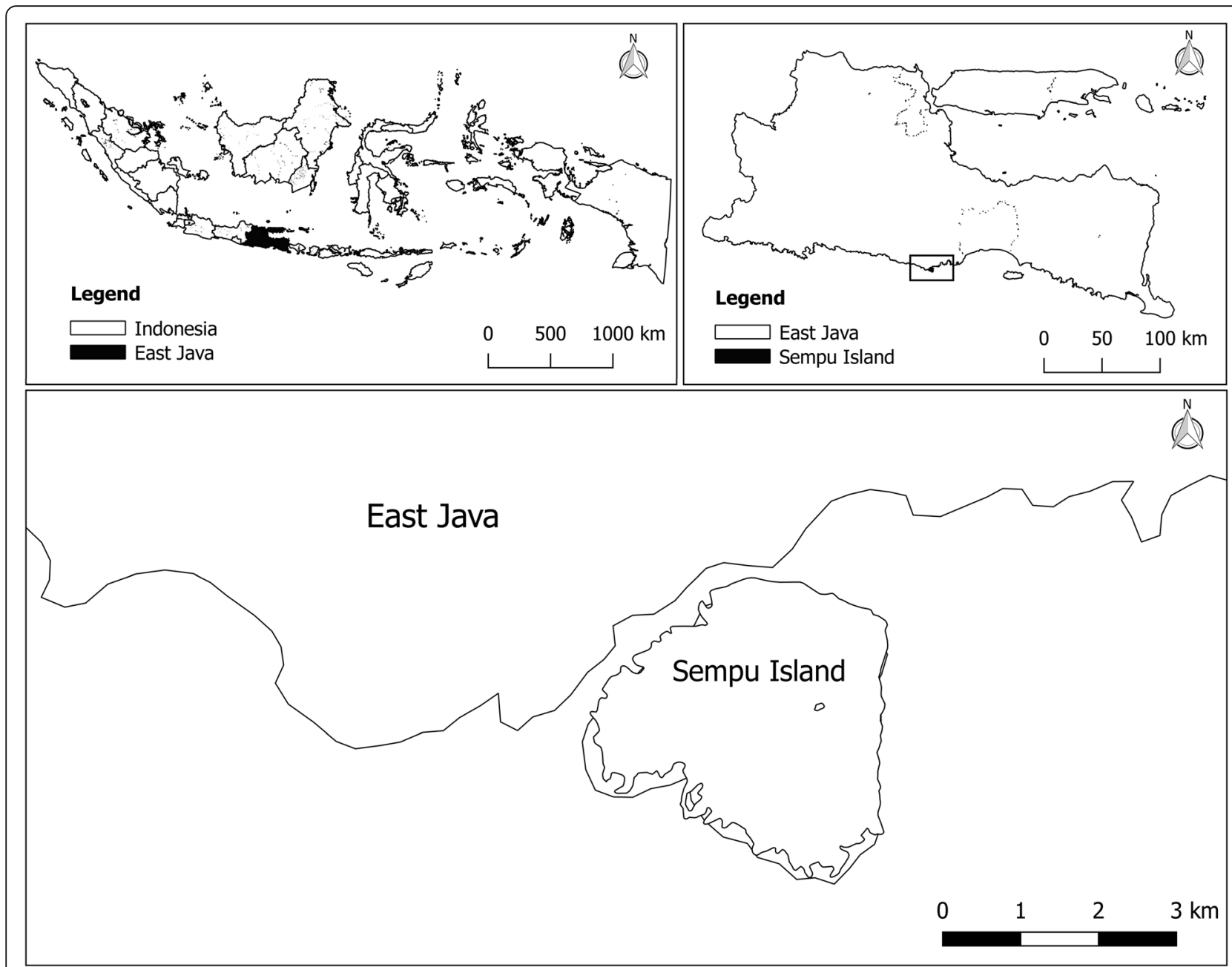

Fig. 6 Map of the Sempu Island Nature Reserve, East Java, Indonesia

ecosystems, including mangrove, coastal sandy, karst, and low land (Rindyastuti et al. 2018a).

\section{Plant species}

Plant species included in this study were 30 species in total, including 3 invasive species, composed of one C4 grass (Imperata cylindrica) and two C3 shrubs (Lantana camara and Chromolaena odorata) (Fig. 7), and 27 native species, including native $\mathrm{C} 4$ grass, $\mathrm{C} 3$ shrubs, trees, and mangrove species, growing in the Sempu Island and Java mainland (Table 6). The selected species both invasive and native species have been inventoried in the previous study by Rindyastuti et al. 2018b). The occurrence of plant invasiveness was also analyzed ecologically (Hapsari et al. 2020). Therefore, plant species was selected based on plant abundance and ecological information about the invasiveness. Additionally, three invasive species were chosen because they are notorious invasive species in study regions and many other countries.
For ecophysiological analyses, the selected twelve species were analyzed from TRY database for the data of SLA and seed dry weight, 5 species (included 2 invasive shrubs and 1 invasive grass) for leaf photosynthetic rate per unit leaf dry weight, and 14 species (included 1 invasive shrub and 1 invasive grass) for seed dry weight, while anatomical analyses were conducted on a subset of grass and shrubs, including 3 invasive species and 5 native species. The grass investigated in the anatomical study included one invasive C4 grass (I. cylindrica) and two native C4 grass (Ischaemum muticum and Thuarea involuta), while the shrubs included two invasive species (L. camara and C. odorata) and three native species (Wollastonia biflora, Pemphis acidula, and Casearia flavovirens).

Twenty-seven native species were selected as reference species. We used 27 native species because we need to find more generalized differences in plant ecophysiological characteristics. Instead, we used 5 native species for anatomical traits because we tried to compare species in 


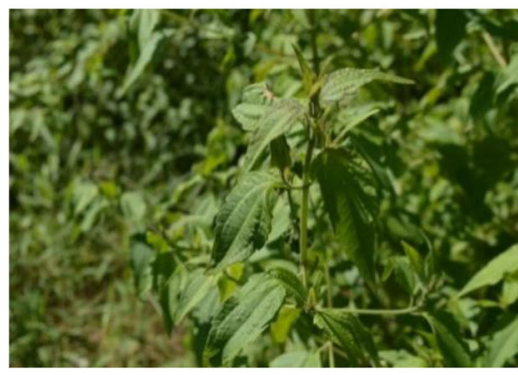

(a)

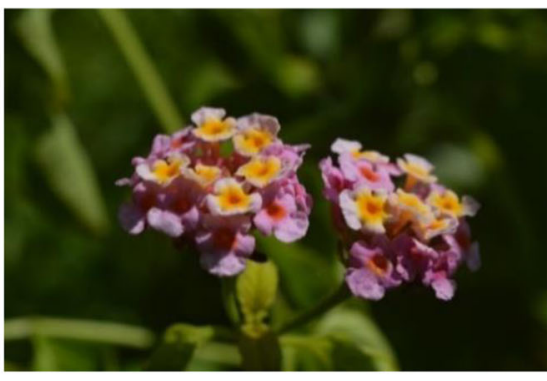

(b)

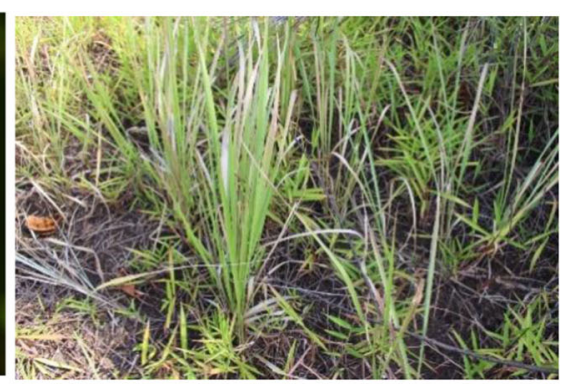

(c)

Fig. 7 Morphological appearance of invasive alien species (IAS) in Sempu Island. a Chromolaena odorata. b Lantana camara. c Imperata cylindrica

detail and the deep analysis with fewer species (still, as many as possible we can).

I. cylindrica (cogon grass; Poaceae) is a C4 perennial cosmopolitan grass distributed throughout the tropics and subtropics. It is native in southern Europe and Africa (Weber 2003). Other sources mentioned that it was originated from East Africa and South-East Asia (Tjitrosoedirdjo et al. 2016). This native species become very invasive in Indonesia (Tjitrosoedirdjo et al. 2016; Weber 2003). I. cylindrica produces culms from creeping underground rhizomes and exhibits slender, flat, and linearlanceolate leaves with serrated margins and an off-center prominent white midrib. I. cylindrica is well adapted to high sunlight, frequent burning, and nutrient-poor soils (Fig. 7a; MacDonald 2004; Holzmueller and Jose 2010). I. cylindrica is one of the 10 most difficult to control noxious weeds and 100 most invasive species in the world (USDA 2012; Lowe et al. 2000).

The invasive alien shrubs, L. camara (wild sage; Verbenaceae), is a pantropical weed native of Central and South America and the Caribbean. Leaves of $L$. camara have a strong aroma. Flowers are small, multi-colored, stalked, densely arranged in flat-topped clusters, with a corolla that comprises a narrow tube with four short spreading lobes (Fig. 7b; Priyanka and Joshi 2013). The other shrub species, $C$. odorata (Asteraceae), is a pioneer shrub native to America, which was introduced into India and became an invasive alien species in Southeast Asia. C. odorata has a brittle highly branched stem, ovate-triangular leaves, and fibrous root system (Fig. 7c; Muniappan et al. 2009). Both species are fast-growing, form dense bushes, have allelopathic effects, and produce small seeds that can travel long distances via wind dispersal, thus enabling rapid invasion in new areas (Hapsari et al. 2020). L. camara and C. odorata are listed among the 100 most invasive species in the world (Lowe et al. 2000).

\section{Plant traits}

In this study, we analyzed and compared ecophysiological and leaf anatomical traits (both qualitative and quantitative) of native and invasive plant species in Sempu Island between similar and different life forms. Data on the ecophysiological traits, including SLA, seed dry weight, leaf photosynthetic rate per unit leaf dry weight, and plant height were obtained from the TRY Plant Trait Database (https://www.try-db.org/TryWeb/ Home.php) (Kattge et al. 2011). TRY database was used because traits in the database represent a variety of measurements from different locations, so more generalized results could be concluded.

The data of SLA and seed dry weight of twelve species (including 2 invasive shrubs), leaf photosynthetic rate per unit leaf dry weight of 5 species (including 2 invasive shrubs and grass), and plant height of 14 species (including 2 invasive species) were extracted from TRY database. The data for each parameter was analyzed to obtain the median values. Median values were used to minimize the influence of extreme data and it represent averaged characteristics of plants. For SLA, 10 woody plant species, which are locally grown in Indonesian ecosystems were measured and cited from the previous study (Rindyastuti and Sancayaningsih 2018). Combining the data from TRY database and measurements hopefully could increase the number of species and data variation which cover different environment variables from various locations. For plant height, many species and plant samples were used and some of them are maximum height for the species studied. These data were used to minimize the environmental variables that may affect the results and conclusion. Besides the comparison among plant species, the mean values of each parameter between invasive and native species were compared to represent general outperformance between native and invasive species.

Leaf anatomical traits were obtained from leaf transverse sections and anatomical characterizations. Three invasive and 5 native species were sampled from coastal areas of Sempu Island during field study in November 2018. The five leaves from each of three different plant species were sampled for replications. Briefly, transverse 
Table 6 List of plant species examined in this study, along with their life form, status, and photosynthesis type

\begin{tabular}{|c|c|c|c|c|c|c|c|}
\hline No. & Species name & $\begin{array}{l}\text { Number of } \\
\text { samples }\end{array}$ & Family & Life form & Status & $\begin{array}{l}\text { Photosynthesis } \\
\text { type }\end{array}$ & Trait source \\
\hline 1 & Imperata cylindrica (L.) Raeusch. & $2-8$ & Poaceae & Grass & Invasive & C4 & $\begin{array}{l}\text { Leaf anatomy, TRY p.t } \\
\text { database }\end{array}$ \\
\hline 2 & Ischaemum muticum L. & 3 & Poaceae & Grass & Native & C4 & Leaf anatomy \\
\hline 3 & Thuarea involuta (G.Forst.) R.Br. ex Sm. & 3 & Poaceae & Shrub & Native & C4 & Leaf anatomy \\
\hline 4 & Lantana camara L. & $1-4$ & Verbenaceae & Shrub & Invasive & C3 & $\begin{array}{l}\text { Leaf anatomy, TRY p.t. } \\
\text { database }\end{array}$ \\
\hline 5 & $\begin{array}{l}\text { Chromolaena odorata (L.) R.M.King \& } \\
\text { H.Rob. }\end{array}$ & $1-4$ & Asteraceae & Shrub & Invasive & $\mathrm{C} 3$ & $\begin{array}{l}\text { Leaf anatomy, TRY p.t. } \\
\text { database }\end{array}$ \\
\hline 6 & Wollastonia biflora (L.) DC. & 3 & Asteraceae & Shrub & Native & C3 & Leaf anatomy \\
\hline 7 & Pemphis acidula J.R. Forst. \& G. Forst. & 3 & Lythraceae & Shrub & Native & $\mathrm{C} 3$ & Leaf anatomy \\
\hline 8 & Casearia flavovirens Blume & 3 & Salicaceae & Mangrove & Native & $\mathrm{C} 3$ & Leaf anatomy \\
\hline 9 & Ficus benjamina L. & $1-5$ & Moraceae & Tree & Native & C3 & TRY plant trait database \\
\hline 10 & Terminalia catappa L. & $1-3$ & Combretaceae & Tree & Native & C3 & TRY plant trait database \\
\hline 11 & Spondias pinnata (L. f.) Kurz & $1-3$ & Anacardiacae & Tree & Native & $\mathrm{C} 3$ & TRY plant trait database \\
\hline 12 & Croton tiglium L. & 1 & Euphorbiaceae & Tree & Native & C3 & TRY plant trait database \\
\hline 13 & Diospyros cauliflora Blume & $2-3$ & Ebenaceae & Tree & Native & C3 & TRY plant trait database \\
\hline 14 & Barringtonia asiatica (L.) Kurz & 3 & Lecythidaceae & Tree & Native & C3 & Rindyastuti et al. (2018b) \\
\hline 15 & $\begin{array}{l}\text { Dracontomelon dao (Blanco) Merr. \& } \\
\text { Rolfe }\end{array}$ & 3 & Anacardiacae & Tree & Native & C3 & Rindyastuti et al. (2018b) \\
\hline 16 & Heritiera littoralis Aiton & 3 & Malvaceae & Tree & Native & C3 & Rindyastuti et al. (2018b) \\
\hline 17 & Diospyros discolor Willd. & 3 & Ebenaceae & Tree & Native & C3 & Rindyastuti et al. (2018b) \\
\hline 18 & Calophyllum inophyllum L. & 3 & Clusiaceae & Tree & Native & C3 & Rindyastuti et al. (2018b) \\
\hline 19 & Antidesma bunius (L.) Spreng. & 3 & Phyllanthaceae & Tree & Native & C3 & Rindyastuti et al. (2018b) \\
\hline 20 & Schleichera oleosa (Lour.) Merr. & 3 & Sapindaceae & Tree & Native & C3 & Rindyastuti et al. (2018b) \\
\hline 21 & Syzygium cumini (L.) Skeels & 3 & Myrtaceae & Tree & Native & C3 & Rindyastuti et al. (2018b) \\
\hline 22 & $\begin{array}{l}\text { Madhuca longifolia (J.Koenig ex L.) } \\
\text { J.F.Macbr. }\end{array}$ & 3 & Sapotaceae & Tree & Native & C3 & Rindyastuti et al. (2018b) \\
\hline 23 & Adenanthera pavonina $\mathrm{L}$. & 3 & Leguminosae & Tree & Native & $\mathrm{C} 3$ & TRY plant trait database \\
\hline 24 & $\begin{array}{l}\text { Pandanus tectorius Parkinson ex Du } \\
\text { Roi }\end{array}$ & 1 & Pandanaceae & Tree & Native & C3 & TRY plant trait database \\
\hline 25 & Ficus copiosa Steud. & 1 & Moraceae & Tree & Native & C3 & TRY plant trait database \\
\hline 26 & Morinda citrifolia L. & 1 & Rubiaceae & Tree & Native & C3 & TRY plant trait database \\
\hline 27 & Vitex trifolia L. & 1 & Vitaceae & Tree & Native & C3 & TRY plant trait database \\
\hline 28 & Ipomoea pes-caprae (L.) r. Br. & 1 & Convolvulaceae & Herbs & Native & C3 & TRY plant trait database \\
\hline 29 & $\begin{array}{l}\text { Pandanus tectorius Parkinson ex Du } \\
\text { Roi }\end{array}$ & 1 & Pandanaceae & $\begin{array}{l}\text { Screw } \\
\text { pine }\end{array}$ & Native & C3 & TRY plant trait database \\
\hline 30 & Kleinhovia hospita L. & 1 & Malvaceae & Tree & Native & $\mathrm{C} 3$ & TRY plant trait database \\
\hline
\end{tabular}

sections of leaves were prepared and fixed in $70 \%$ ethanol. The fixed leaves were sliced into thin sections using a hand microtome, stained with $1 \%$ Safranin, and observed under the Olympus CX21 light microscope, with three replications. Quantitative traits were measured using the Optilab Image Raster software (Optilab Advance). The photosynthetic type of plants in the anatomical study was clarified from the previous study and anatomical observation under the microscopes, especially from the presence of bundle sheath showing Kranz anatomy. Additionally, an equal comparison was performed between $\mathrm{C} 3$ and $\mathrm{C} 4$ plants. We compared invasive $\mathrm{C} 3$ shrubs with native C3 shrubs and between invasive C4 grass with native C4 grass. Total chlorophyll content (sum of chlorophyll a and chlorophyll b) was measured using the CCM-200 plus Chlorophyll Content Meter (Opti-Sciences, Inc., USA), with three replications per species and five replications per leaf (Perez-Harguindeguy et al. 2013). 
More native species were analyzed than invasive plants to find more generalized differences in plant characteristics. Among 27 native species chosen for comparison, there are endemic species which were not found in other countries. Unfortunately, some traits about them are very limited in TRY database. Therefore, available species were used for the comparison of each trait, still as many species as possible. Different species were used for each trait to reveal more general outperformance of invasive species over the natives in an island ecosystem. The analyses of outperformance of invasive species were focused on the invasive plants co-occur in a similar ecosystem rather than on the per-plant species analysis.

\section{Statistical analysis}

Before performing the analysis of variance, ecophysiological and anatomical data were tested for data normality using Kolmogorov-Smirnov and homoscedasticity using Run test. Leaf anatomical data was not normal; therefore, it was normalized using matrix covariance before performing PCA. One-way analysis of variance (ANOVA) and Tukey's test were performed using MINI TAB ver.14 to compare plant traits between native and invasive species at a confidence level of $95 \%(P \leq 0.05)$. Multivariate ordination PCA was conducted using the statistical software Paleontological Statistics (PAST; version 3.15) to identify the association pattern between species and quantitative traits using a correlation matrix and scatter biplot (Hammer et al. 2001).

\section{Abbreviations}

IAS: Invasive alien species; SLA: Specific leaf area; PCA: Principal component analysis; RGR: Relative growth rate

\section{Acknowledgements}

This work was supported by a grant from the 2020 Research Fund of Andong National University.

\section{Authors' contributions}

RR designed the research, wrote the manuscript, and analyzed the data. LH analyzed the data, edited, and reviewed the manuscript. CB designed the research, reviewed the methodology, and approved the research and final manuscript. All authors contributed to the review and editing of the manuscript. The author(s) read and approved the final manuscript.

\section{Funding}

This work was supported by a grant from the 2020 Research Fund of Andong National University.

\section{Availability of data and materials}

Please contact author for a data request.

\section{Ethics approval and consent to participate}

Not applicable.

\section{Consent for publication}

Not applicable.

\section{Competing interests}

The authors declare that they have no competing interests.

\section{Author details}

${ }^{1}$ Purwodadi Botanic Garden, Research Center for Plant Conservation and Botanic Gardens, Indonesian Institute of Sciences, Jl. Raya Surabaya-Malang Km. 65, Purwodadi, Pasuruan, East Java 67163, Indonesia. ${ }^{2}$ Department of Biological Sciences and Biotechnology, College of Life Sciences \& Biotechnology, Andong National University, 1375 Gyeongdong-ro, Andong, Gyeongsangbukdo 36729, Korea.

Received: 7 September 2020 Accepted: 26 November 2020

Published online: 07 January 2021

\section{References}

Bajwa AA, Chauhan BS, Faroog M, Shabbir A, Adkins SW. What do we really know about alien plant invasion? A review of the invasion mechanism of one of the world's worst weeds. Planta. 2016;244:39-57.

Banovetz SJ, Scheiner SM. The effect of seed mass on the seed ecology of Coreopsis lanceolata. Am Midl Nat. 1994;131(1):65-74.

Baruch Z, Goldstein G. Leaf construction cost, nutrient concentration, and net $\mathrm{CO}_{2}$ assimilation of native and invasive species in Hawaii. Oecologia. 1999; 121:183-92.

Brantley ST, Young DR. Linking light attenuation, sunflecks, and canopy architecture in mesic shrub thickets. Plant Ecol. 2009;206:225-36.

Brym ZT, Lake JK, Allen D, Ostling A. Plant functional traits suggest novel ecological strategy for an invasive shrub in an understory woody plant community. J Appl Ecol. 2011;48:1098-106.

Burns JH, Winn AA. A comparison of plastic responses to competition by invasive and non-invasive congeners in the Commelinaceae. Biol Invasions. 2006;8: 797-807.

Calado H, Fonseca C, Vergilio M, Costa A, Moniz F, Gil A, Dias JA. Small islands conservation and protected areas. J Integr Coast Zone Manag. 2014;14(2): $167-74$.

CBD (Convention on Biological Diversity). Invasive alien species. www.cbd.int/ invasive. 2010. Accessed 2 May 2018.

Daehler CC. Performance comparison of co-occuring native and alien invasive plants: implications for conservation and restoration. Ann Rev Ecol Evol Syst. 2003;34:183-211

Dozier H, Gaffney JF, McDonald SK, Johnson ERRL, Shilling DG. Cogongrass in the United States: History, ecology, impacts, and management. Weed Technol. 1998;12:737-43.

Drenovsky RE, Grewell BJ, D'Antonio CM, Funk JL, James JJ, Molinari N, Parker IM, Richards CL. A functional trait perspective on plant invasion. Ann Bot. 2012; 110:141-53.

Fahn A. Plant anatomy. 3rd ed. Oxford: Pergamon Press; 1982.

Farnsworth EJ, Meyerson LA. Comparative ecophysiology of four wetland plant species along a continuum of invasiveness. Wetlands. 2003;23(4):750-62.

Fenner M. Seed ecology: Chapman and Hall Ltd.; 1985. p. 2-10.

Foloruso AE, Awosode OD. Comparative anatomy of invasive and non-invasive species in the family Asteraceae in Nigeria. Int J Biol Chem Sci. 2013;7(5): 1804-19.

Gallagher RV, Randall RP, Leishman MR. Trait differences between naturalized and invasive plant species independent of residence time and phylogeny. Conserv Biol. 2014;29(2):360-9.

Global Invasive Species Database (GISD). Species profile Chromolaena odorata. 2015. Available from: http://www.iucngisd.org/gisd/species.php?sc=47. Accessed 2 Dec 2019

Graebner RC, Callaway RM, Montesinos D. Invasive species grows faster, competes better, and shows greater evolution toward increased seed size and growth than exotic non-invasive congeners. Plant Ecol. 2012;213:545-53.

Greene DF, Johnson EA. Seed mass and dispersal capacity in wind-dispersed diaspores. Oikos. 1993;67:69-74.

Grime JP. The C-S-R model of primary plant strategies-origins, implications and tests. In: Gottlieb LD, Jain SK, editors. Plant Evolutionary Biology. Dordrecht: Springer; 1988; https://doi.org/10.1007/978-94-009-1207-6_14.

Grotkopp E, Rejmánek M. High seedling relative growth rate and specific leaf area are traits of invasive species: phylogenetically independent contrasts of woody angiosperms. Am J Bot. 2007:94(4):526-32.

Grotkopp E, Rejmánek M, Rost TL. Toward a causal explanation of plant invasiveness: seedling growth and life-history strategies of 29 Pine (Pinus) Species. Am Nat. 2002;159(4):396-419.

Hakim L, Leksono AS, Purwaningtyas D, Nakagoshi N. Invasive plant species and the competitiveness of wildlife tourist destination: a case of Sadengan 
Feeding Area at Alas Purwo National Park, Indonesia. J Intl Dev Coop. 2005; 12(1):35-45.

Hameed M, Ashraf M. Anatomical adaptation to salinity in cogon grass (Imperata cylindrica (L). Raeuschel) from the Salt Range, Pakistan. Plant Soil. 2009:322: 229-38.

Hamilton MA, Murray BR, Cadotte MW, Hose GC, Baker AC, Harris CJ, Licari D. Life-history correlates of plant invasiveness at regional and continental scales. Ecol Lett. 2005;8:1066-74

Hammer $\varnothing$, Harper DAT, Ryan PD. Past: paleontological statistics software package for education and data analysis. Palaeontol Electron. 2001;4(1):9.

Hapsari L, Abywijaya IK, Nurfadilah S, Rindyastuti R. Diversity and ecology of understory plant in Sempu Island, East Java, Indonesia. Biotropia 2020;27(3): 222-37.

Hapsari L, Basith A, Novitasiah HR. Inventory of invasive plant species along the corridor of Kawah ljen Nature Tourism Park, Banyuwangi, East Java. J. Indones Tour Dev Stud. 2014;2(1):1-9.

Hodkinson DJ, Askew AP, Thompson K, Hodgson JG, Bakker JP, Bakker RM. Ecological correlates of seed size in the British flora. Funct Ecol. 2002;12(5): 762-6.

Holzmueller EJ, Jose S. Invasion success of cogon grass, an alien C4 perennial grass, in the southeastern United States: exploration of the ecological basis. Biol Invasion. 2010;13(2):435-42.

James JJ, Drenovsky RE. A basis for relative growth rate differences between native and invasive forb seedlings. Rangel Ecol Manag. 2007;60(4):395-400.

Junaedi DI, Dodo. Exotic plants in Halimun Salak corridor: micro-environment, detection and risk analysis of invasive plants. Biotropia. 2014;21(1):38-52.

Kattge J, Diaz S, Lavorel S, Prentice IC, et al. TRY —a global database of plant traits. Glob Change Biol. 2011;17(9):2905-35.

Kudo Y, Mutagien Z, Simbolon H, Suzuki E. Spread of invasive plants along trails in two national parks in West Java, Indonesia. Tropics. 2014;23(3):99-110.

Lack AJ, Evans DE. Instant notes of plant biology. Oxford: BIOS Scientific Publishers Limited; 2001.

Lambers $\mathrm{H}$, Poorter $\mathrm{H}$. Inherent variation in growth rate between higher plants: a search for physiological causes and ecological consequenses. Adv Ecol Res. 1992;23:187-261.

Lambers H, Chapin FS, Pons TL. Plant physiological ecology. New York: SpingerVerlag; 1998. p. 299-322.

Leishman MR, Haslehurst T, Ares A, Baruch Z. Leaf trait relationships of native and invasive plants: community- and global-scale comparisons. New Phytol. 2007; 176:635-43.

Liao Z-Y, Scheepens JF, W-Tao L, Fang WR, Y-Long Z, Y-Long F. Biomass reallocation and increased plasticity might contribute to successful invasion of Chromolaena odorata, Flora; 2019. https://doi.org/10.1016/fflora.2019.05.004.

Lowe S, Browne M, Boudjelas S, De Poorter M. 100 of the world's worst invasive alien species. A selection from the global invasive species database. Published by The Invasive Species Specialist Group (ISSG) a specialist group of the Species Survival Commission (SSC) of the World Conservation Union (IUCN); 2000. p. 12. First published as special lift-out in Aliens 12, December 2000. Updated and reprinted version: November 2004.

MacDonald GE. Cogongrass (Imperata cylindrica)-biology, ecology, and management. Critical Rev Plant Sci. 2004;23(5):367-80.

Marchante H, Freitas H, Hoffmann J. Seed ecology of an invasive alien species, Acacia Longifolia (Fabaceae), in Portuguese dune ecosystems. Am J Bot. 2010; 97(11):1780-90

Maschinski J. Impacts of ungulate herbivores on a rare willow at the southern edge of its range. Biol Conserv. 2001;101:119-30.

Mcalpine KG, Jesson LK, Kubien DS. Photosynthesis and water-use efficiency: a comparison between invasive (exotic) and non-invasive (native) species. Austral Ecol. 2008:33:10-9.

McDowell SCL. Photosynthetic characteristics of invasive and noninvasive species of Rubus (Rosaceae). Am J Bot. 2002;89:1431-8.

Moles AT, Warton DI, Warman L, Swenson NG, Laffan SW, Zanne AE, Pitman A, Hemmings FA, Leishman MR. Global patterns in plant height. J Ecol. 2009;97: 923-32.

Moodley D, Geerts S, Richardson DM, Wilson JRU. Different traits determine introduction, naturalization and invasion success in woody plants: Proteaceae as a test case. PLoS One. 2013;8(9):e75078.

Moravcová L, Pyšek P, Jarošík V, Pergl J. Getting the right traits: reproductive and dispersal characteristics predict the invasiveness of herbaceous plant species. PLoS One. 2015;10(4):e0123634.
Morris TL, Esler KJ, Barger NN, Jacobs SM, Cramer MD. Ecophysiological traits associated with the competitive ability of invasive Australians Acacia. Divers Distrib. 2011;17:898-910.

Muniappan R, Reddy GVP, Raman A. Biological control of tropical weeds using arthropods. USA: Cambridge University press; 2009. p. 130-40.

Nagaraj N, Reese JC, Kirkham MB, Kofoid K, Campbell LR, Loughin TM. Relationship between chlorophyll loss and photosynthetic rate in Greenbug (Homoptera) damaged sorghum. J Kansas Entomol Soc. 2002;75(2):101-9.

Namagada M, Krekling T, Lye KA. Leaf anatomical characteristics of Ugandan species of Festuca L. (Poaceae). S Afr J Bot. 2009;75:52-9.

Nurse LA, Sem G, Hay JE, Suarez AG, Wong PP, Briguglio L, Ragoonaden S. Small island states. Climate change 2001: impacts, adaptation, and vulnerability. Cambridge: Cambridge University Press; 2001.

Pattinson RR, Goldstein G, Ares A. Growth, biomass allocation and photosynthesis of invasive and native Hawaian rainforest species. Oecologia. 1998;117(4):449-59.

Perez-Harguindeguy N, et al. New handbook for standardize measurement of plant functional traits worldwide. Aust J Bot. 2013;61:167-234.

Poorter $\mathrm{H}$, Remkes $\mathrm{C}$. Leaf area ratio and net assimilation rate of 24 wild species differing in relative growth rate. Oecologia. 1990;83:553-9.

Priyanka N, Joshi PK. A review of Lantana camara studies in India. Int J Sci Res Publ. 2013;3(10):1-11.

Pugnaire IF, Valladares F. Handbook of functional plant ecology. New York: Marcel Dekker, Inc.; 1999. p. 81-121.

Quan GM, Mao DJ, Zhang JE, Xie JF, Xu HQ, An M. Response of invasive Chromolaena odorata and two coexisting weeds to contrasting irradiance and nitrogen. Photosynthetica. 2015;53:419-29.

Rejmánek M. What makes species invasive. In: Pysek, Prach K, Rejmánek M, Wade M, editors. Plant invasions - general aspects and special problems. Amsterdam: Academic Publishing; 1995.

Rejmánek M. A theory of seed plant invasiveness: the first sketch. Biol Conserv. 1996;78:171-81.

Rejmánek M, Richardson DM. What attributes make some plant species more invasive? Ecology. 1996;77:1655-166

Rindyastuti R, Sancayaningsih RP. The growth strategies analysis of ten woody plant species for effective revegetation. Biotropia. 2018;25(1):43-55.

Rindyastuti R, Abywijaya IK, Rahadiantoro A, rrawanto R, et al. Keanekaragaman Tumbuhan Pulau Sempu dan Ekosistemnya. Jakarta: LIPI Press. [Indonesian]; 2018a.

Rindyastuti R, Rachmawati D, Sancayaningsih RP, Yulistyarini T. Ecophysiological and growth characters of ten woody plant species in determining their carbon sequestration. Biodiversitas. 2018b;19(2):610-9.

Riveron-Giro FB, Damon AD, Garcia-Gonzalez A, Solis-Montero L, Aguilar-Romero O, Ramirez-Marcial N, Nieto G. Anatomy of the invasive orchid Oeceoclades maculata: ecological implications. Bot J Linnean Soc. 2017;184:94-112.

Roger D. Invasive alien species: global perspectives. In: Proceedings of the national workshop on invasive alien species, 20 October 2003, Kuala Lumpur: Organized by the Department of Agriculture, Ministry of Agriculture, Malaysia in collaboration with ASEANET and CAB International - SEA Regional Office; 2003.

Sarijeva G, Knapp M, Lichtenthaler HK. Differences in photosynthetic activity, chlorophyll and carotenoid levels, and in chlorophyll fluorescence parameters in green sun and shade leaves in Ginkgo and Fagus. J Plant Physiol. 2007;164:950-5.

Shipley B. Trade-offs between net assimilation rate and specific leaf area and determining relative growth rate: relationship with daily irradiance. Funct Ecol. 2002;16:682-98.

Sukistyanawati A, Pramono H, Suseno B, Cahyono H, Andriyono S. Wild animals inventarisation in Sempu Island Nature Reserve. Jurnal IImiah Perikanan dan Kelautan. 2016;8(1):26-35 [Indonesian].

Sutomo E, van Etten, Wahab L. Proof of Acacia nilotica stand expansion in Bekol Savanna, Baluran National Park, East Java, Indonesia through remote sensing and field observations. Biodiversitas. 2016;17(1):96-101.

Thompson K, Band SR, Hodgson JG. Seed size and shape predict persistence in soil. Funct Ecol. 1993;7:236.

Thomson FJ, Moles AT, Auld TD, Kingsford RT. Seed dispersal distance is more strongly correlated with plant height than with seed mass. J Ecol. 2011;99: 1299-307.

Tjitrosoedirdjo SS. Inventory of the invasive alien plant species in Indonesia. Biotropia. 2005;25:60-73.

Tjitrosoedirdjo SS, Mawardi I, Tjitrosoedirdjo S. 75 important invasive plant species in Indonesia: SEAMEO BIOTROP Southeast Asian Regional Centre for Tropical Biology; 2016. p. 115. https://biotrop.org/publication/show/75important-invasive-alien-plant-species-in-indonesia. 
Trimanto, Hapsari L. Botanical survey in thirteen montane forests of Bawean Island Nature Reserve, East Java Indonesia: Flora diversity, conservation status, and bioprospecting. Biodiversitas. 2016;17(2):832-46.

USDA National Resource Conservation Service: Plant Database. http://plants.usda. gov/javal. Accessed 12 Oct 2012

Van Kleunen M, Weber E, Fischer M. A meta-analysis of trait differences between invasive and non-invasive plant species. Ecol Lett. 2010;13:235-45.

Vanderwoude C, Scanlan JC, Davis B, Funkhouser S. Plan for national delimiting survey for Siam weed. Queensland Government: Natural Resources and Mines Land Protection Services; 2005.

Wang C, Liu J, Xiao H, Zhou J. Differences in leaf functional traits between Rhus typhina and native species. Clean Soil Air Water. 2016;44(11):1591-7.

Weber E. Invasive plant species of the world. A reference guide to environmental weeds. Wallingford: CABI Publishing; 2003.

Westoby M. A leaf-height-seed (Ihs) plant ecology strategy scheme. Plant Soil. 1998;199:213-27.

Westoby M, Jurado E, Leishman M. Comparative evolutionary ecology of seed size. Trends Ecol Evol. 1992;7:368-72.

Witkowski ETF, Wilson M. Changes in density, biomass, seed production and soil seed banks of the non-native invasive plant, Chromolaena odorata, along a 15 year chronosequence. Plant Ecol. 2001;152:13-27.

\section{Publisher's Note}

Springer Nature remains neutral with regard to jurisdictional claims in published maps and institutional affiliations.

Ready to submit your research? Choose BMC and benefit from:

- fast, convenient online submission

- thorough peer review by experienced researchers in your field

- rapid publication on acceptance

- support for research data, including large and complex data types

- gold Open Access which fosters wider collaboration and increased citations

- maximum visibility for your research: over $100 \mathrm{M}$ website views per year

At BMC, research is always in progress.

Learn more biomedcentral.com/submissions 